\title{
Study of degradation and evaluation of model parameters of micromorph silicon photovoltaic modules under outdoor long term exposure in Jaén, Spain
}

\author{
Sofiane Kichou ${ }^{1 *}$, Elif Abaslioglu, Santiago Silvestre ${ }^{1}$, Gustavo Nofuentes ${ }^{2}$, \\ Miguel Torres-Ramírez ${ }^{2}$, Aissa Chouder ${ }^{3}$
}

\footnotetext{
${ }^{1}$ MNT Group, Electronic Engineering Department, Universitat Politécnica de Catalunya (UPC) BarcelonaTech, C/Jordi Girona 1-3, Campus Nord UPC, 08034 Barcelona, Spain.

* Corresponding author. Telephone/fax number: +34 93 4017491/+34 93 4016756; email: kichousofiane@gmail.com

2 IDEA Research Group, University of Jaén, Campus de Las Lagunillas, 23071, Jaén, Spain.

${ }^{3}$ Univ. M'sila, Fac. Technologies, Dep. Génie Electrique, BP 166 Ichbelia 28000 M'sila, Algeria.
}

\section{Abstract}

The analysis of the degradation of tandem amorphous silicon (a-Si:H) and microcrystalline silicon ( $\mu$-Si:H): Micromorph thin-film photovoltaic (TFPV) modules and its impact on the output power of a PV array under outdoor long term exposure located in Jaén (Spain) is addressed in this work. Furthermore, the evolution of main solar cell model parameters is evaluated by means of parameters extraction techniques from monitored data of the PV system in real operation of work. The degradation rate and the stabilization period of micromorph TFPV modules, as well as the results of the evolution of each of the solar cell model parameters along the outdoor long-term exposure are analysed in order to gain a better understanding of changes in performance of micromorph TFPV modules and the behaviour of the output power of the PV generator.

Keywords: Micromorph PV modules, model parameters extraction, degradation rate. 


\section{Introduction}

Thin-film photovoltaic (TFPV) technologies based on cadmium-telluride (CdTe), copper indium gallium selenide (CIGS) and silicon take around 10\% of the global PV market that is mainly dominated by crystalline silicon (c-Si) PV modules. Thin-film silicon PV modules are based on either amorphous silicon (a-Si:H) or microcrystalline silicon ( $\mu \mathrm{c}-\mathrm{Si}: \mathrm{H})$ and have plenty of advantages such as lower temperature coefficient relative to $\mathrm{C}-\mathrm{Si}$ and polycrystalline PV modules, low quantity silicon usage as raw material, low-cost manufacturing process and flexibility in product design. However, several weaknesses and challenges in TFPV technologies have been discussed such as low conversion efficiency and long term technological risks in the field performance in terms of durability when compared with the crystalline technology [Campa et al. 2014].

A list of studies have reported analysis of outdoor performance and degradation of PV modules of several technologies under different climatic conditions [ Kaplanis and Kaplani, 2011; Jordan and Kurtz, 2013; Sharma and Chandel, 2013; Bouraiou et al., 2015; Chandel et al., 2015]. Likewise, performance evaluation of specific TFPV modules based on: CIGS [Al-Otaibi et al., 2015], CdS/CdTe [ Rawat et al., 2016], a-Si:H and $\mu \mathrm{c}-\mathrm{Si}: \mathrm{H}$ [Tripathi et al., 2014] were also reported. These studies have shown that the degradation rate is mainly associated to the PV module technology and, in addition, TFPV modules present higher degradation rates than polycrystalline and C-Si PV modules (Jordan and Kurtz, 2013; Muñoz-García et al., 2012). On the other hand, a-Si:H suffers from a performance degradation called light-induced degradation (LID) due to the Staebler-Wronski effect (SWE) [Staebler, D. L. and Wronski, C. R.,1977; Hussin et al., 2015]. It was demonstrated that a-Si:H TFPV modules are degraded mainly by the SWE effect, when compared to other TFPV technologies [Meyer and van Dyk, 2003; van Dyk et al., 2007; Radue and van Dyk, 2010;]. This degradation phenomenon is also present but is much less severe in $\mu c-S i: H$ TFPV.

Micromorph TFPV modules are formed by micromorph tandem (a-Si:H/ $\mu-$ $\mathrm{Si}: \mathrm{H})$ solar cells that allow a more effective use of the solar spectrum than C_Si solar cells because the band-gaps of both materials form an ideal combination; 
a-Si:H has a band-gap in the range of 1.7-1.8 eV, while $\mu \mathrm{c}$-Si:H has the same band-gap as a c-Si wafer, i.e. $1.12 \mathrm{eV}$ [ Shah et al., 2013]. In order to mitigate the degradation of the a-Si:H top cell due to the SWE effect, it needs to be as thin as possible, typically 0.2-0.3 $\mu \mathrm{m}$. However, a thinner a-Si:H layer limits the short-circuit current of the solar cell if a good matching with the short-circuit current density of the bottom cell is not achieved. For this purpose, an intermediate reflecting layer (IRL) is typically implemented between the top and bottom cells in order to reflect back part of the light that is not absorbed during its first passage through the top a-Si:H cell. Then, the IRL enables a reduction of the a-Si:H solar cell thickness, while keeping its short-circuit current density matched with the one of the bottom cell [Campa et al. 2014].

In this work we analyse the behavior of micromorph TFPV modules under outdoor long term exposure in Jaén, Spain. The period under scrutiny ranges from late July 2011 to December 2014.

On the other hand, the variation of main solar cell model parameters is also evaluated by means of parameter extraction techniques. The parameter extraction has as input the daily monitored data of the PV system in real operation of work and calculates the temporal evolution of main solar cell model parameters able to reproduce the actual behavior of the whole PV system with a good accuracy.

The rest of this paper is organized as follows: An overview of the PV array under study and its model is given in section 2. The parameter extraction technique, as well as the degradation analysis methodology is also introduced in Section 2. Section 3 describes the experimental PV validation of the parameter extraction algorithm array used in this study. The results and discussion are presented in Section 4. Finally, the conclusions of the study are given in Section 5. 


\section{Methodology}

\subsection{Description of the PV system}

The PV system under study is sited in Jaén. Jaén is a dry and sunny inland Spanish city with a Continental-Mediterranean climate. Table 1 summarizes main climate parameters of that city sited in the south of Spain, as can be seen in Fig. 1.

Table 1. Annual average values of main meteorological parameters recorded in Jaén over 30 years [Spanish National Institute of Meteorology, 1997]

\begin{tabular}{cllllll}
\hline $\begin{array}{l}\text { Horizontal } \\
\text { irradiation } \\
\left(\mathrm{kWh} \cdot \mathrm{m}^{-2}\right)\end{array}$ & $\begin{array}{l}\text { Ambient } \\
\text { temperature } \\
\left({ }^{\circ} \mathrm{C}\right)\end{array}$ & $\begin{array}{l}\text { Minimum } \\
\text { ambient } \\
\text { temperature } \\
\left({ }^{\circ} \mathrm{C}\right)\end{array}$ & $\begin{array}{l}\text { Maximum } \\
\text { ambient } \\
\text { temperature } \\
\left({ }^{\circ} \mathrm{C}\right)\end{array}$ & $\begin{array}{l}\text { Relative } \\
\text { humidity }\end{array}$ & $\begin{array}{l}\text { Rainfall } \\
(\%)\end{array}$ & $\begin{array}{l}\text { Barometric } \\
\text { pressure } \\
(\mathrm{mPa})\end{array}$ \\
\hline 2038 & 16.9 & 11.4 & 22.4 & 63 & 558 & 954.1 \\
\hline
\end{tabular}

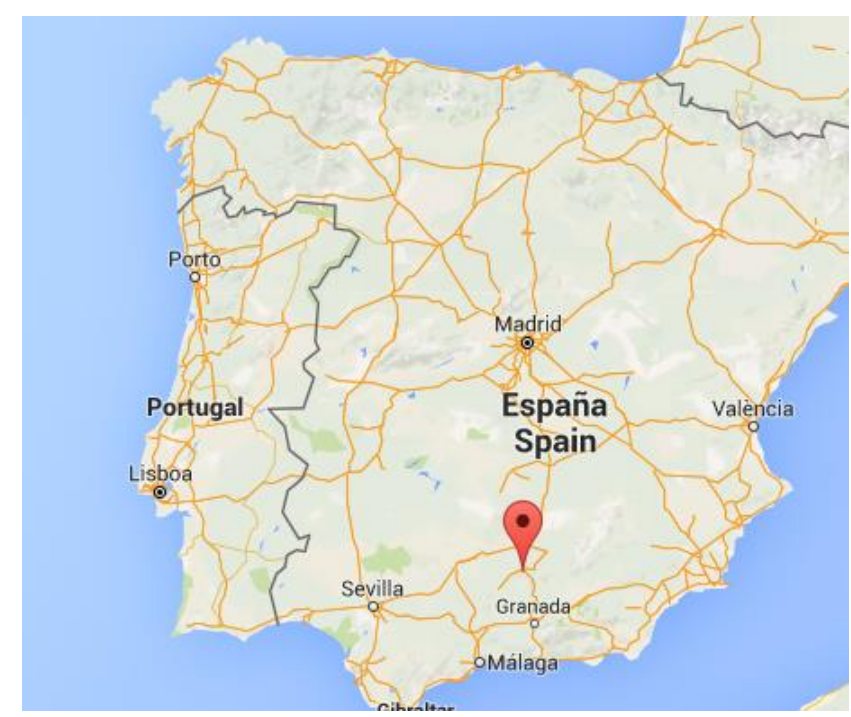

Fig. 1. City of Jaén : Latitude: $37^{\circ} 47^{\prime} 14.35^{\prime \prime} \mathrm{N}$

Longitude: 3ㅇ 46' 39.73 " W, Altitude: $511 \mathrm{~m}$.

The PV array comprises 8 micromorph TFPV modules, with 4 parallelconnected strings of 2 series-connected PV modules each $(\mathrm{Np}=4, \mathrm{Ns}=2)$. Main electrical characteristics at STC of this PV field are given in Table 2. 
Table 2. Main electrical characteristics at STC of the PV array.

\begin{tabular}{|c|c|c|c|c|c|c|}
\hline PV module & $\begin{array}{l}\text { Configuration } \\
\text { Nsm x Npm }\end{array}$ & $\begin{array}{l}\text { Maximum } \\
\text { power }(\mathrm{W})\end{array}$ & $\begin{array}{l}\text { Open } \\
\text { circuit } \\
\text { voltage } \\
\text { (V) }\end{array}$ & $\begin{array}{l}\text { Short } \\
\text { circuit } \\
\text { current } \\
\text { (A) }\end{array}$ & $\begin{array}{l}\text { Voltage } \\
\text { at } \\
\text { maximum } \\
\text { power } \\
\text { point }(\mathrm{V})\end{array}$ & $\begin{array}{l}\text { Current } \\
\text { at } \\
\text { maximum } \\
\text { power } \\
\text { point }(A)\end{array}$ \\
\hline $\mathrm{a}-\mathrm{Si} / \mu-\mathrm{Si}$ & $2 \times 4$ & 880 & 284 & 5 & 216 & 4.08 \\
\hline
\end{tabular}

The PV system was installed outdoors at the beginning of July 2011 in a south sriented $30^{\circ}$ tilted platform located on the flat roof of the High Technical School building in the University of Jaen (UJA) in the city of Jaén and it is connected to a single-phase grid-tied SMA ${ }^{\mathrm{TM}}$ Sunny Boy SB1200 inverter. Two SMA $^{\text {TM }}$ Sunny SensorBox devices installed on a metal plate in the same plane as the PV field were used to measure cell and ambient temperatures together with wind speed. Moreover, two Pt 100 resistive thermal detectors (RTD) are used as module temperature sensors. The in-plane irradiance was monitored by means of a Kipp \& Zonen ${ }^{\mathrm{TM}}$ CMP21 pyranometer, which is also installed on the $P V$ array plane. Onsite measurements of DC voltage and current are recorded at the inverter input with a sampling rate of 5 minutes.

\subsection{PV Array model and parameter extraction}

The well-known one diode five parameter model is considered in this work for modeling the micromorph solar cell, where the relation between the output current and voltage is defined as follows:

$$
I=I_{p h}-I_{O}\left[\exp \left(\frac{V+R_{s} I}{n V t}\right)-1\right]-\frac{V+R_{s} I}{R_{s h}}
$$

where: $I_{p h}$ is the photocurrent, $I_{0}$ is the diode reverse saturation current, $n$ is the diode ideality factor, $R_{S}$ and $R_{s h}$ are the series and shunt resistances respectively, $V t$ is the thermal voltage. $I$ and $V$ are the output current and voltage.

The model of the solar cell describe by Eq. (1) can be scaled up to the model of the PV array taking into account the configuration of the PV array: Number of PV modules connected in series by string: $N_{s m}$, and the number of 
parallel strings forming part of the PV array: $N_{p m}$, as well as the internal configuration and the number of solar cells contained in the PV module [Silvestre et al., 2014].

Several studies based on the simulation of PV systems on different software environments have applied this model and results obtained were experimentally validated with success [Chouder and Silvestre, 2010; Chouder et al., 2012; Chouder et al., 2013; Yu et al., 2013; Di Vincenzo and Infield, 2013; Chine et al., 2014 ]. In this work Matlab/Simulink environment is used for the simulations and the parameter extraction.

In our study we are interested in the investigation of the variation of the solar cell model parameters of the micromorph silicon PV modules when exposed outdoors. Therefore, a parameter extraction technique is included in order to find the set of solar cell model parameters able to reproduce the actual behavior of the whole PV system with the best accuracy.

The parameter extraction technique used in this study is the same used in [Kichou et al., 2016], where the monitored data: Current, Voltage and Power at the DC output of the PV array together with the in-plane irradiance (G) and cell temperature $\left(T_{c}\right)$ profiles, are used as inputs for the parameter extraction algorithm in order to estimate the set of model parameters of the solar cells forming the PV array.

Considering the number of parallel strings of solar cells present in the PV array, Np, Eq. 1 can be written as follows:

$$
I=N_{p}\left(I_{p h}-I_{d}-I_{s h}\right)
$$

where I is the DC output current of the PV array.

For any arbitrary value of $G$ and $T_{c}$, the photocurrent, $I_{p h}$, is given by:

$$
I_{p h}=\frac{G}{G^{*}} I_{s c c}+k_{i}\left(T_{c}-T_{c}^{*}\right)
$$

where $G^{*}$ and $T^{*}{ }_{c}$ are respectively the irradiance and cell temperature at standard test conditions (STC) : $1000 \mathrm{~W} / \mathrm{m}^{2} \quad(\mathrm{AM} 1.5)$ and $25^{\circ} \mathrm{C}, k_{i}$ is the 
temperature coefficient of the current and $I_{s c c}$ is the solar cell short circuit current at STC.

The diode current, $I_{d}$, included in Eq. 2 is given by:

$$
I_{d}=I_{o}\left[e^{\left(\frac{\frac{V}{N_{S}}+\frac{I R_{s}}{N_{p}}}{n V_{t}}\right)}-1\right]
$$

where 10 is the saturation current of the diode and $N s$ is the number of solar cells connected in series in each string.

Finally, the shunt current, $I_{s h}$, included in Eq. 2 can be calculated from:

$$
I_{s h}=\frac{\frac{V}{N_{s}}+\frac{I R_{s}}{N_{p}}}{R_{s h}}
$$

where $V$ is the $\mathrm{DC}$ output voltage of the PV array.

The parameter extraction algorithm evaluates: $I p h, l o, R s, R s h$, and $n$ by using Eqs. $2-5$ and actual daily profiles of monitored electrical parameters namely, current and voltage at the DC output of the PV array, together with $G$ and TC. Then, a nonlinear regression algorithm based on the LevenbergMarquardt method was applied to both data sets: The daily monitored data from the PV array in real conditions of work and simulation results generated by using the described model, in order to minimize the following quadratic function [Chouder and Silvestre, 2009; Durisch and Mayor, 2003; Kichou et al., 2016]:

$$
S(\theta)=\sum_{i=1}^{N}[I i-I(V i, \theta)]^{2}
$$

where $\theta=f(I p h, l o, R s, R s h, n)$

\subsection{Effective peak power of the PV array}

The degradation analysis is based on the variation of the output power of the PV array along the monitoring campaign. The effective peak power of a PV 
array, $P^{*}$, at STC is defined as follows [Martínez-Moreno et al., 2012; Muñoz et al., 2015]:

$$
P_{M}^{*}=\frac{G^{*} P_{D C}}{G\left[1+\gamma\left(T_{C}-T_{c}^{*}\right)\right]}
$$

where $P_{D C}, G$ and $T_{C}$ are the DC output power of the PV array, the irradiance and cell temperature respectively, $G^{*}$ and $T_{c}{ }^{*}$ are the irradiance and temperature at STC, respectively, and $\gamma$ is the power temperature coefficient of the PV modules.

The power coefficient temperature, $\gamma$, can be calculated as follows [Spataru et al., 2015]:

$$
\gamma=\frac{1}{P_{\max }} \frac{\partial P_{\max }}{\partial T}
$$

where $P_{\max }$ is the maximum power of PV modules at STC and the reference temperature is $25^{\circ} \mathrm{C}$.

The evaluation of $P^{*}{ }_{M}$ requires a previous filtering of irradiance values in order to avoid the influence of operational anomalies [Martínez-Moreno et al., 2012; Muñoz et al., 2015]. In this study the data corresponding to low levels of irradiance $\left(G<700 \mathrm{~W} / \mathrm{m}^{2}\right)$ are discarded before the calculation of $P^{*}{ }_{M}$ values. As the solar spectrum distribution at in-plane irradiance levels above $700 \mathrm{~W} / \mathrm{m}^{2}$ closely matches that of the AM $1.5 \mathrm{G}$ standard reference spectrum in the city of Jaén [Nofuentes et al., 2014], no spectral effects have been included in Eq. 7.

\subsection{Power-Irradiance technique}

In this work, the technique presented by Hussin [Hussin et al., 2015] was considered. This technique permits assessing the degradation of PV modules exposed under outdoor conditions in terms of power line transition in between two boundaries indicators; predicted initial and stabilized data values of PV array DC power outputs. 
The predicted initial, $P d c_{\text {init, }}$ and stabilized, $P d c_{\text {stab }}$, data values depend on the measured plane-of-array irradiance $(G)$, module temperature $(T c)$, and can be calculated by using the following equations:

$$
\begin{aligned}
& P d c_{i n i t}=N_{s m} \cdot N_{p m} \cdot P m_{i n i t} \cdot \eta \cdot G_{e f f} \cdot(1+k v \cdot \Delta T) \cdot(1-k i \cdot \Delta T) \\
& P d c_{s t a b}=N_{s m} \cdot N_{p m} \cdot P m_{s t a b} \cdot \eta \cdot G_{e f f} \cdot(1+k v \cdot \Delta T) \cdot(1-k i \cdot \Delta T) \\
& G_{e f f}=\frac{G}{G_{n}} \\
& \Delta T=T_{c}-T_{n}
\end{aligned}
$$

where $N_{s m}$ and $N_{p m}$ are the number of PV modules connected in series and parallel respectively, $P m_{\text {init }}$ is the initial measured peak power of PV module, $k v$ and $k i$ are the voltage and current temperature coefficients respectively provided in the manufacturer's data sheet $\left({ }^{\circ} \mathrm{C}^{-1}\right), P d c_{s t a b}$ is the predicted array DC power referred to stabilized, $P m_{\text {stab }}$ is the stabilized peak power of the PV module found in the manufacturer's data sheet, $\eta$ is the efficiency referred to all general system losses which changes between 0.89 in summer and 0.86 in winter months, Gn and $T n$ are the reference irradiance and cell temperature respectively at STC .

As it has been previously mentioned, a data filtering process was carried out in order to avoid problems of uncertainties caused by low values of irradiance $\left(G<700 \mathrm{~W} / \mathrm{m}^{2}\right)$.

Linear regression equations are obtained by using a Linear Correlation Approach (LCA) from the actual PV array DC output power for each month described by the following empirical equation:

$$
P d c=A_{G r} \cdot G+C
$$

where $P d c$ is the array DC output power, $A_{G r}$ is the gradient, $G$ is the plan-ofarray irradiance and $C$ is the ordinate value of $P d c$ at $G=0$.

Finally, the monthly gradient values of each empirical equation can be plotted to observe the degradation rate and determine the stabilization period upon this type of micromorph PV modules [Hussin et al, 2015]. 


\section{Experimental}

\subsection{Parameter extraction procedure validation}

The parameter extraction algorithm calculates the set of values for the five model parameters of the solar cell: Iph, Rs, Rsh, Io and $n$ by using Eqs. 2-5 described in section 2.2 that allow reproducing the actual behavior of the PV array. For this purpose, the daily monitored data set: Output DC current and voltage, irradiance and temperature of the PV array in real conditions of work are used as input data of the algorithm and it is executed until function $S(\theta)$, given by Eq. 6, is minimized. Table 3 shows the set of solar cell model parameters obtained corresponding to October 6, 2011.

Table 3. Extracted solar cell model parameters

\begin{tabular}{cccccc}
\hline Day & Io $[\boldsymbol{A}]$ & Jsco $[A]$ & $\operatorname{Rp}[\Omega]$ & $\operatorname{Rs}[\Omega]$ & $\boldsymbol{n}$ \\
\hline $\mathbf{0 6 / 1 0 / 2 0 1 1}$ & $9,1510^{-8}$ & 0,021461 & 9,6602 & 0,045587 & 1,2642 \\
\hline
\end{tabular}

Fig. 2 shows a comparison of the DC output power of the PV array, monitored and evaluated by using the set of model parameters obtained from the parameter extraction algorithm for that day. As it can be seen a good agreement is found between simulation results and monitored data. The coefficient of variation of the root mean square errors, CV(RMSE) between both data sets, monitored and calculated by using the set of model parameters, are given in Table 4 for the DC output current, voltage and power of the PV array respectively.

Table 4. CV(RMSE) obtained for main electrical parameters of the PV array

\begin{tabular}{ccc}
\hline RMS_Current & RMS_Voltage & RMS_Power \\
\hline$[\%]$ & {$[\%]$} & {$[\%]$} \\
1,290 & 2,444 & 2,600 \\
& &
\end{tabular}




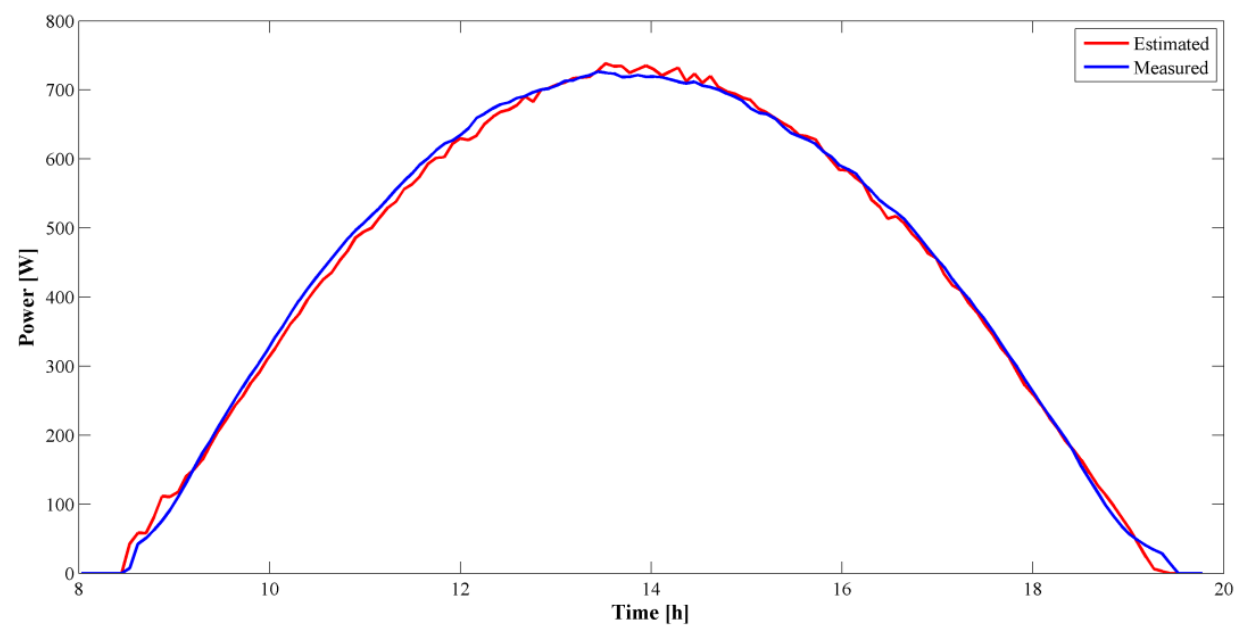

Fig. 2. Measured versus estimated DC output power obtained by using the set of the extracted solar cell model parameters.

\section{Results and discussion}

\subsection{Evolution of the effective peak power of the PV array}

The evolution of the effective peak power of the PV array, $P^{*} M$, and the monthly radiation, $\mathrm{H}$, along the monitoring campaign are shown in Fig. 3.

As it can be seen, an initial important decrease of the effective peak power can be clearly identified and after that, the variation of the $P^{*}{ }_{M}$ follows the climate seasonal changes.

The initial decrease in output power of the array is followed by an increase over the summer months, a decrease over winter months and once again an increase over summer months. As the solar cells contain a thin film amorphous layer, the regeneration on summer months can be assigned to light-induced annealing [Meyer and van Dyk, 2003 ], spectral effects [Carlson, 2003 ] and to the thermal regeneration [Yamawaki et al., 1997; Ruther et al., 2008 ]. 


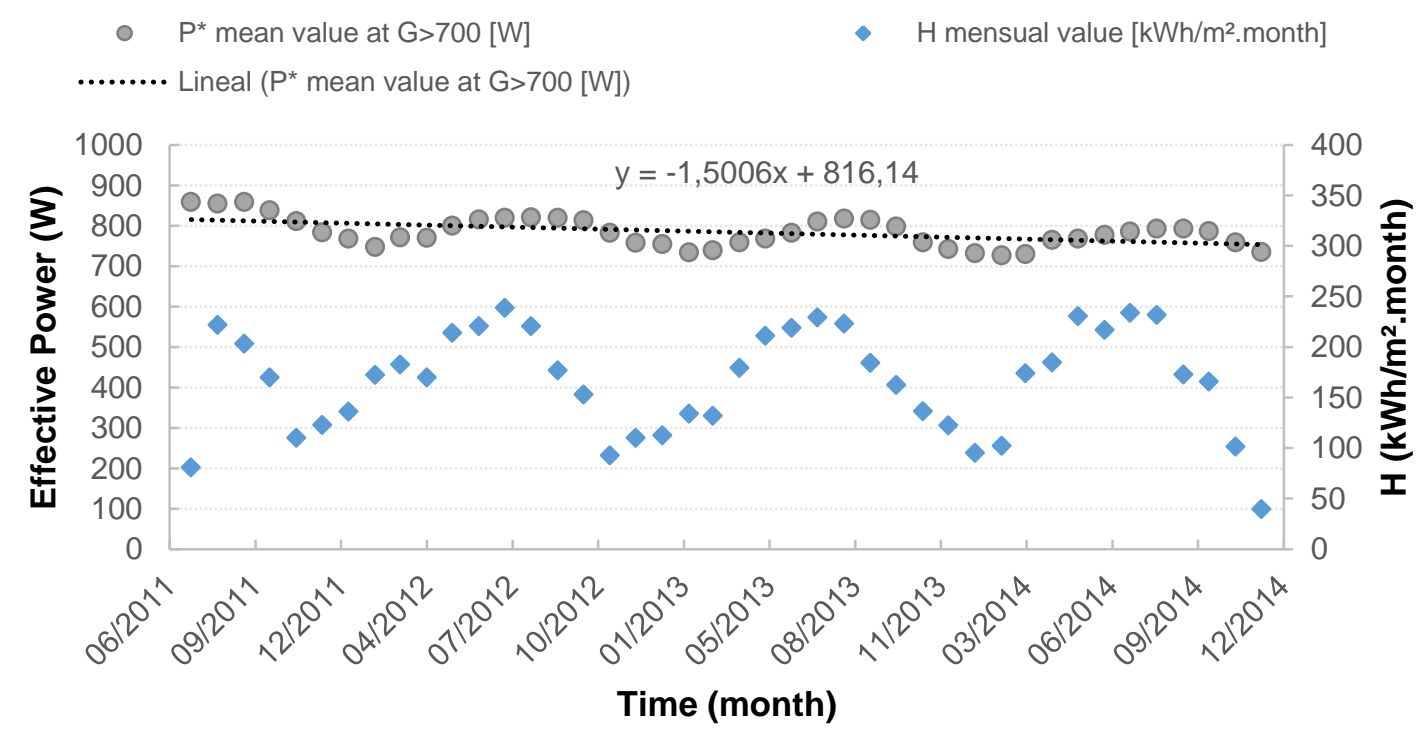

Fig. 3. The effective peak power of the $P V$ array $P^{*}{ }_{M}(W)$ (for $G>700$ $\left.\left[\mathrm{W} / \mathrm{m}^{2}\right]\right)$, and the monthly radiation, $\mathrm{H}$ along exposure period.

A linear least square fitting method was used to estimate de degradation rate, $R_{D}$. This method was applied to the monthly effective peak power, $P^{*} M$, calculated by using Eq. 13 and monitored data. The degradation per year can be calculated by linear regression (LR) as follows [Phinikarides et al., 2014; Sharma et al., 2014]:

The equation of the trend line is:

$$
y=m x+c
$$

where $\mathrm{m}$ is the slope of line and $\mathrm{c}$ is the $\mathrm{y}$ intercept,

Thereby, the degradation per year: $R_{D}(\%)$ can be calculated as follows [Sharma et al., 2014]:

$$
R_{D}=100 \frac{12 m}{c}
$$

The degradation rate calculated from the trend line is found to be: $-2.20 \pm 15$ $\% / y e a r$. The analytical uncertainty reported along with the degradation rate was 
determined from the standard errors of the linear fit. A second monitoring data filtering process was carried out following the procedure used in previous reported studies in order to analyse the stabilization period of the PV array [Hussin et al., 2015]. In this second filtering process, one point for each month of the monitored data for tilted irradiance in the range of $900 \mathrm{~W} / \mathrm{m}^{2}<\mathrm{G}<920$ $\mathrm{W} / \mathrm{m}^{2}$ and working $\mathrm{PV}$ module temperature in the range $53{ }^{\circ} \mathrm{C}<\mathrm{T}<60 \stackrel{\circ}{\circ} \mathrm{C}$ was selected.

From results obtained in the filtering process shown by Fig. 4, the stabilization period was observed to start after four months of operation under the climatic conditions of Jaén. Stabilization periods around up to 2 months have been reported for micromorph TFPV modules under other climatic conditions [Hussin et al., 2015]. A strong initial degradation is observed in the first month of operation, respect to the other monitored months, where the DC power was degraded by about $12.5 \%$. The trend line in Fig. 4 is obtained by sixth polynomial correlation with $\mathrm{R}^{2}$ equal to 0.9499 .

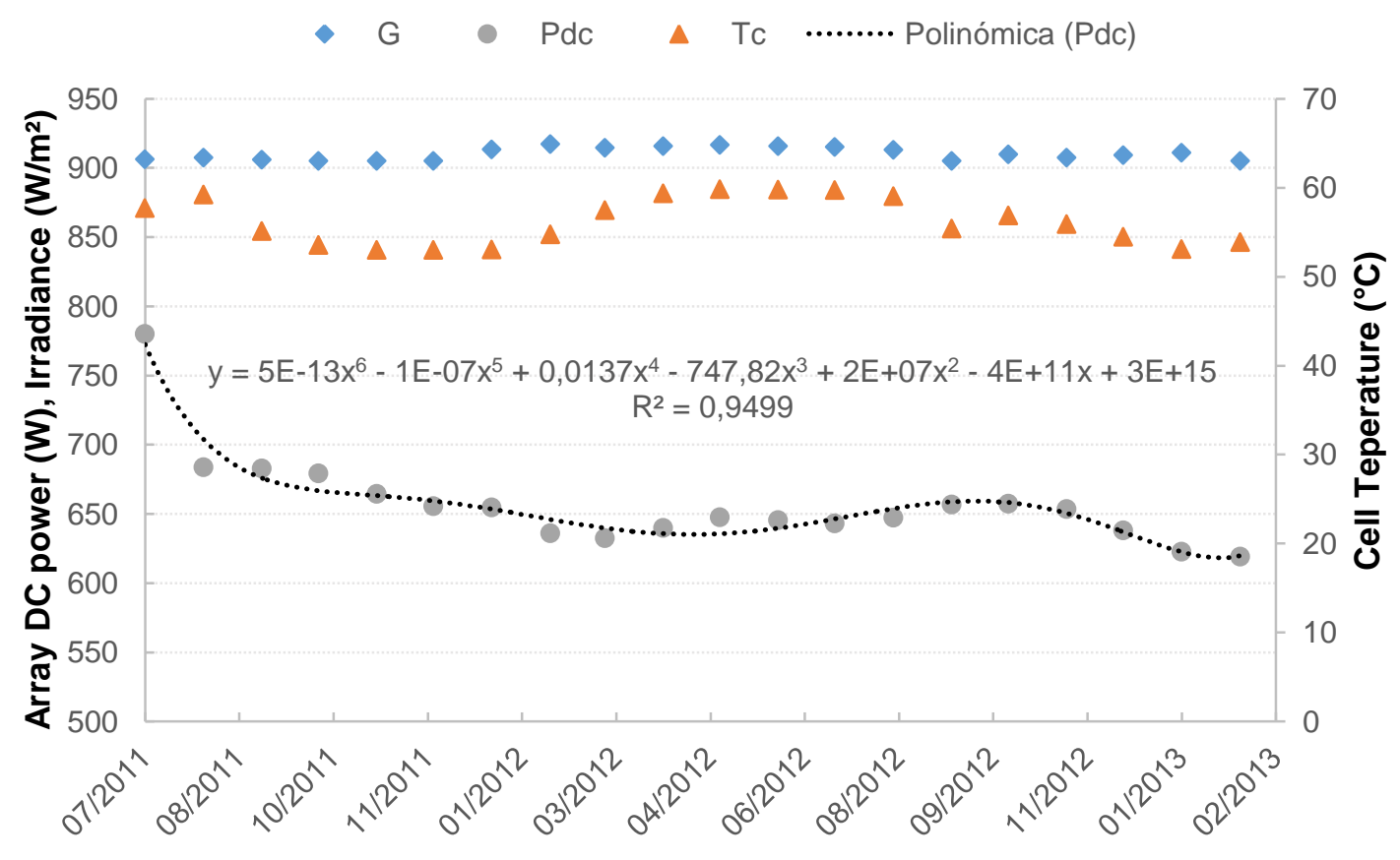

Exposure Time (month)

Fig. 4. Monthly trend line outdoor stabilization process obtained with the selected data of irradiance and cell temperature in the range of

$$
900 \mathrm{~W} / \mathrm{m}^{2}<\mathrm{G}<920 \mathrm{~W} / \mathrm{m}^{2} \text { and } 53^{\circ} \mathrm{C}<\mathrm{T}<60^{\circ} \mathrm{C} \text {. }
$$


Fig. 5 shows the set of data after the first 14 months of operation, when the PV modules are totally stabilised, after a power loss of $16.66 \%$ due to the degradation. The linear trend line with a very small slope, demonstrates that the stabilization level of the PV array output DC power is around $635 \mathrm{~W}$ in the range of $G$ and $T_{c}$ considered in data filtering process. In the following months, it shows a sinusoidal trend attributable to the annealing effects. The effect of seasonal oscillation remains after the stabilization period with variations about $3.18 \%$ from the stabilized level of DC output power.

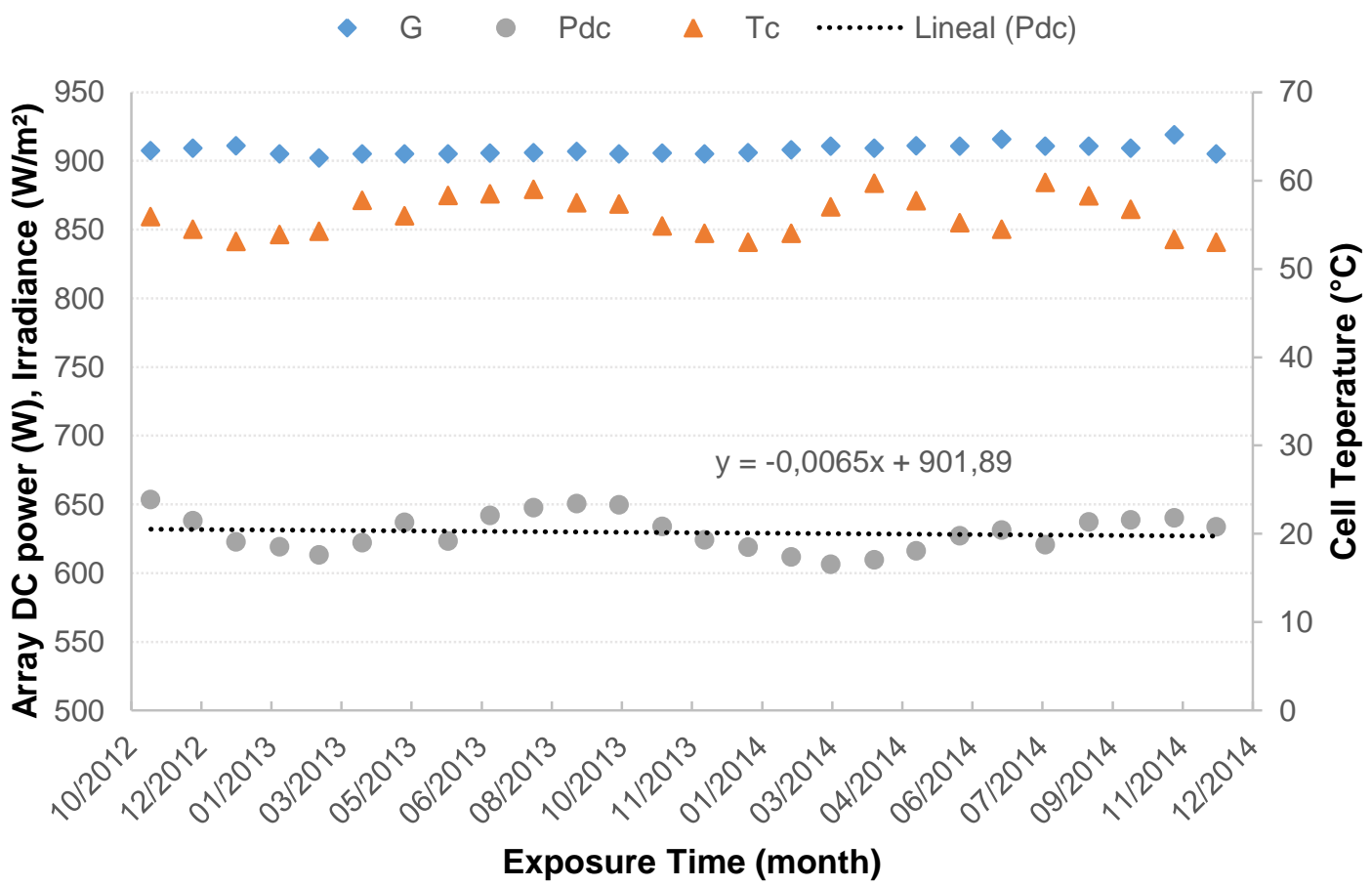

Fig. 5. Trend line showing the stabilization after 14 months of outdoor operation obtained from the selected data of irradiance and cell temperature in the range of $900 \mathrm{~W} / \mathrm{m}^{2}<\mathrm{G}<920 \mathrm{~W} / \mathrm{m}^{2}$ and $53^{\circ} \mathrm{C} C<\mathrm{T}<60 \stackrel{\circ}{\circ} \mathrm{C}$.

\subsection{Power-Irradiance technique results}

The Power-Irradiance technique was applied to assess the degradation rate and the stabilization period of the micromorph TFPV PV modules deployed under outdoor conditions from July 2011 to December 2014.

The measured DC output power of the PV array (blue points), delimited by the two boundaries defined as; initial (red circles) and stable (green stars) 
obtained from equations Eqs. 9-12, are plotted in function of the plane-of-array measured irradiance $(G)$ values for each month of the second semester of each year of the experimental period as illustrated in Fig. 6-9.

From the Figs. 6-9 it can be seen that, the measured DC array output power changes the tendency from the expected initial values to the stabilized ones in the course of time.
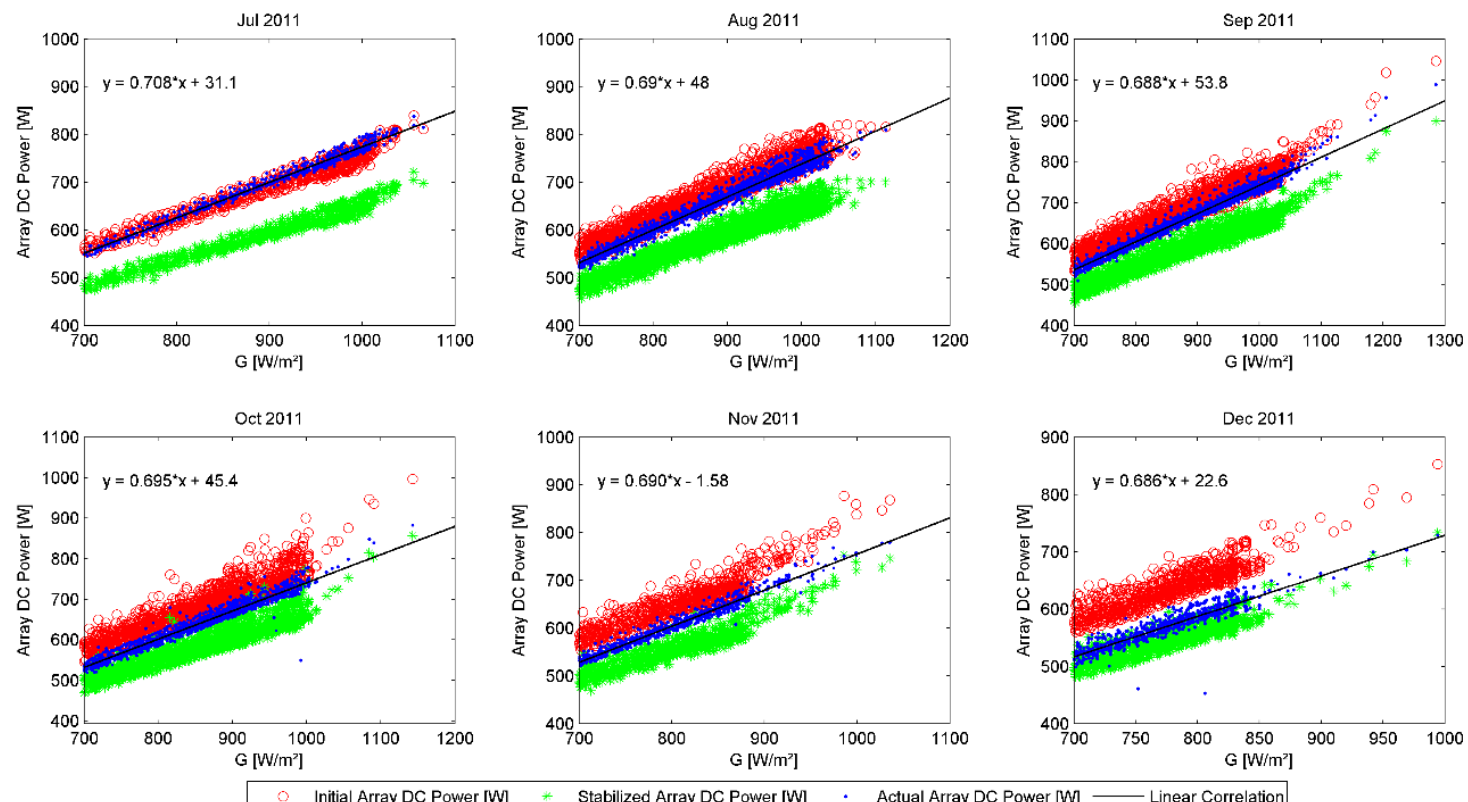

Fig. 6. DC output power evolution from July 2011 to December 2011. 

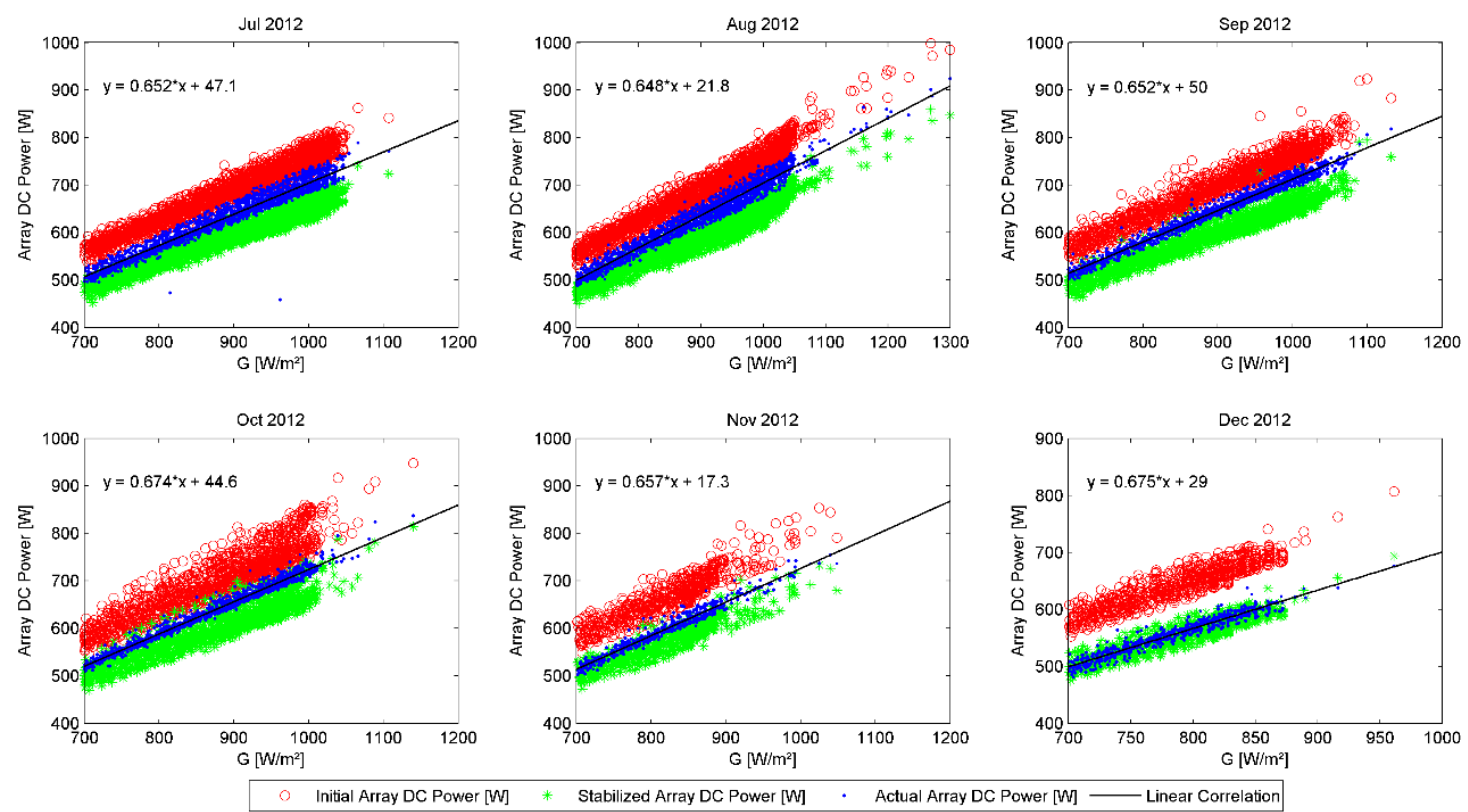

Fig. 7. DC output power evolution from July 2012 to December 2012
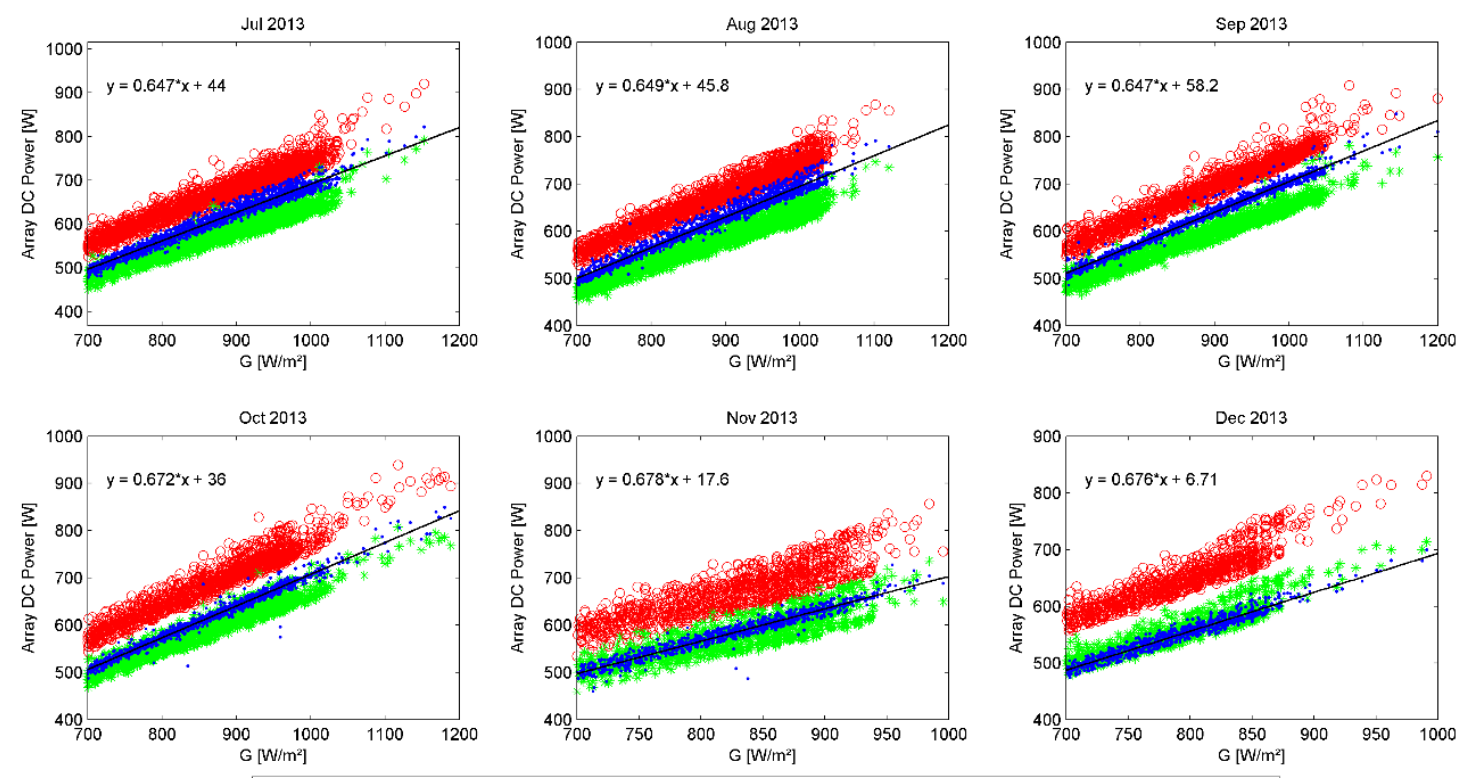

- Initial Array DC Power $[\mathrm{W}]$ * Stabilized Array DC Power $[\mathrm{W}]$ - Actual Array DC Power [W] — Linear Correlation

Fig. 8. DC output power evolution from July 2013 to December 2013 

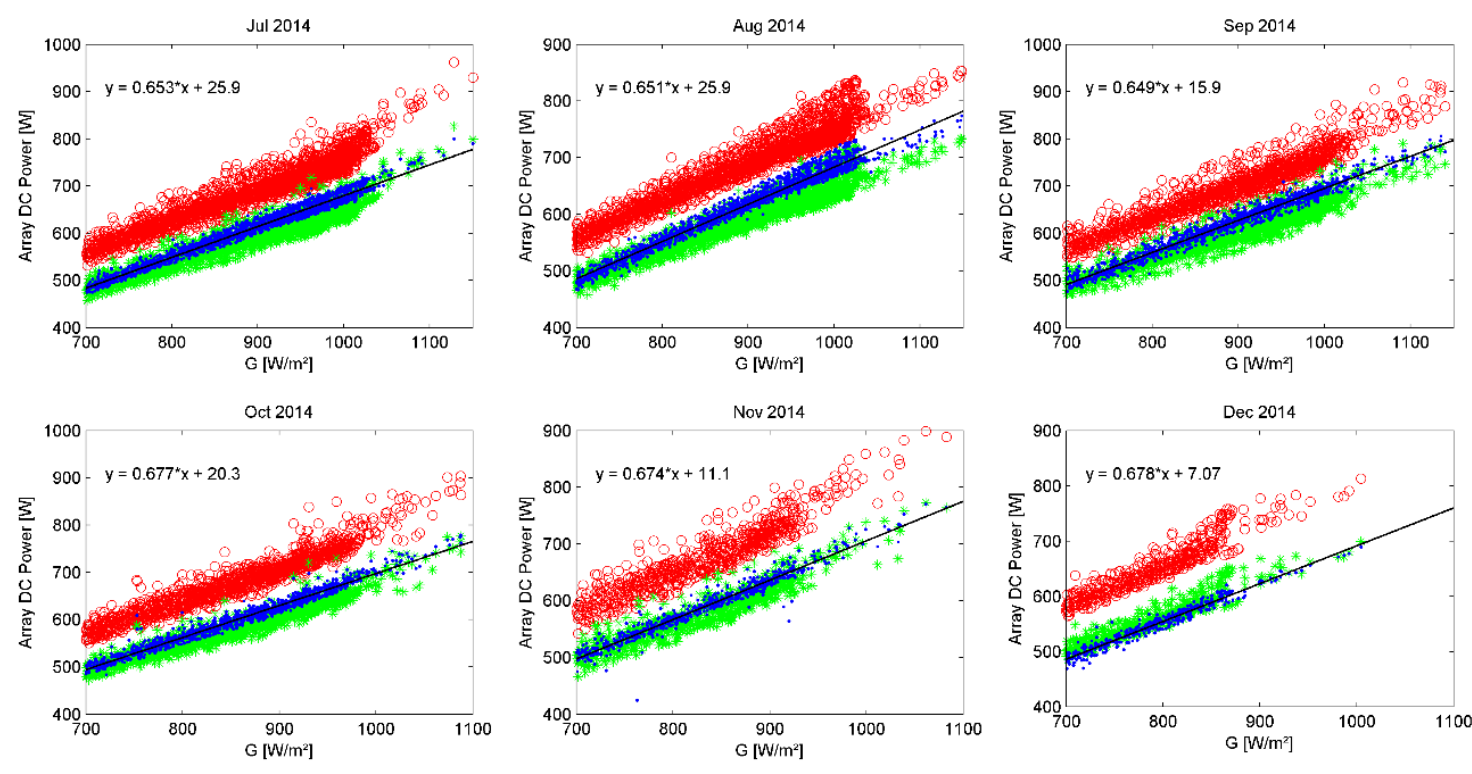

Initial Array DC Power [W] * Stabilized Array DC Power [W] · Actual Array DC Power [M] - Linear Correlation

Fig. 9. DC output power evolution from July 2014 to December 2014

Table 5 illustrates the empirical equations obtained by the LCA applied to the measured PV array DC power output allowing the identification of the degradation and stabilization periods.

Table 5. Monthly empirical equation based on LCA

\begin{tabular}{|c|c|c|c|}
\hline Month & Gradient & $\mathbf{R}^{2}$ & Empirical Equation \\
\hline Jul-11 & 0.708 & 0.9859 & $P d c=0.708 * G+31$ \\
\hline Aug-11 & 0.690 & 0.9714 & $P d c=0.690 * G+48$ \\
\hline Sep-11 & 0.688 & 0.9788 & $P d c=0.688 * G+53.8$ \\
\hline Oct-11 & 0.695 & 0.9579 & $P d c=0.695 * G+45.4$ \\
\hline Nov-11 & 0.690 & 0.9595 & $P d c=0.690 * G-1.58$ \\
\hline Dec-11 & 0.686 & 0.8045 & $P d c=0.686 * G+22.6$ \\
\hline Jan-12 & 0.680 & 0.9390 & $P d c=0.680 * G-2.52$ \\
\hline Feb-12 & 0.673 & 0.9756 & $P d c=0.673 * G+27.83$ \\
\hline Mar-12 & 0.669 & 0.9816 & $P d c=0.669 * G+35.3$ \\
\hline Apr-12 & 0.658 & 0.9786 & $P d c=0.658 * G+31.1$ \\
\hline May-12 & 0.657 & 0.9699 & $P d c=0.657 * G+34$ \\
\hline Jun-12 & 0.650 & 0.9632 & $P d c=0.650 * G+27.9$ \\
\hline Jul-12 & 0.652 & 0.9563 & $P d c=0.652 * G+47.1$ \\
\hline Aug-12 & 0.648 & 0.9638 & $P d c=0.648 * G+21.8$ \\
\hline Sep-12 & 0.652 & 0.9809 & $P d c=0.652 * G+50$ \\
\hline Oct-12 & 0.674 & 0.9795 & $P d c=0.674 * G+44.6$ \\
\hline Nov-12 & 0.657 & 0.9636 & $P d c=0.657 * G+17.3$ \\
\hline
\end{tabular}




\begin{tabular}{|c|c|c|c|}
\hline Dec-12 & 0.675 & 0.9352 & $P d c=0.675^{*} G+29$ \\
\hline Jan-13 & 0,674 & 0.9459 & $P d c=0.674 * G+6.61$ \\
\hline Feb-13 & 0,672 & 0.9768 & $P d c=0.672 * G+12.3$ \\
\hline Mar-13 & 0,671 & 0.9738 & $P d c=0.671^{*} G+23$ \\
\hline Apr-13 & 0,658 & 0.9804 & $P d c=0.658 * G+44.4$ \\
\hline May-13 & 0,657 & 0.9799 & $P d c=0.657^{*} G+30.7$ \\
\hline Jun-13 & 0,653 & 0.9693 & $P d c=0.653 * G+32.1$ \\
\hline Jul-13 & 0,647 & 0.9668 & $P d c=0.647 * G+44$ \\
\hline Aug-13 & 0,649 & 0.9683 & $P d c=0.649 * G+45.8$ \\
\hline Sep-13 & 0,647 & 0.9820 & $P d c=0.647 * G+58.2$ \\
\hline Oct-13 & 0,672 & 0.9776 & $P d c=0.672 * G+36$ \\
\hline Nov-13 & 0,678 & 0.9462 & $P d c=0.678 * G+17.6$ \\
\hline Dec-13 & 0,676 & 0.9439 & $P d c=0.676 * G+6.71$ \\
\hline Jan-14 & 0,675 & 0.9741 & $P d c=0.675^{*} G+13.2$ \\
\hline Feb-14 & 0,669 & 0.9672 & $P d c=0.669 * G+19.1$ \\
\hline Mar-14 & 0,665 & 0.9775 & $P d c=0.665^{*} G+27.5$ \\
\hline Apr-14 & 0,656 & 0.9756 & $P d c=0.656 * G+24$ \\
\hline May-14 & 0,656 & 0.9772 & $P d c=0.656 * G+25.1$ \\
\hline Jun-14 & 0,652 & 0.9820 & $P d c=0.652 * G+29$ \\
\hline Jul-14 & 0,653 & 0.9761 & $P d c=0.653 * G+26$ \\
\hline Aug-14 & 0,651 & 0.9748 & $P d c=0.651 * G+25.9$ \\
\hline Sep-14 & 0,649 & 0.9744 & $P d c=0.649 * G+15.9$ \\
\hline Oct-14 & 0,677 & 0.9727 & $P d c=0.677 * G+20.3$ \\
\hline Nov-14 & 0,674 & 0.9534 & $P d c=0.674 * G+11.1$ \\
\hline Dec-14 & 0,678 & 0.9593 & $P d c=0.678 * G+7.07$ \\
\hline
\end{tabular}

The stabilization period can be estimated by plotting the gradient values obtained from the empirical equation of each month. As it can be seen in Figs. 10 and 11 the stabilization period of these TFPV modules is of four months of exposure under real conditions of solar irradiance and temperature corresponding to the climate of Jaén. 


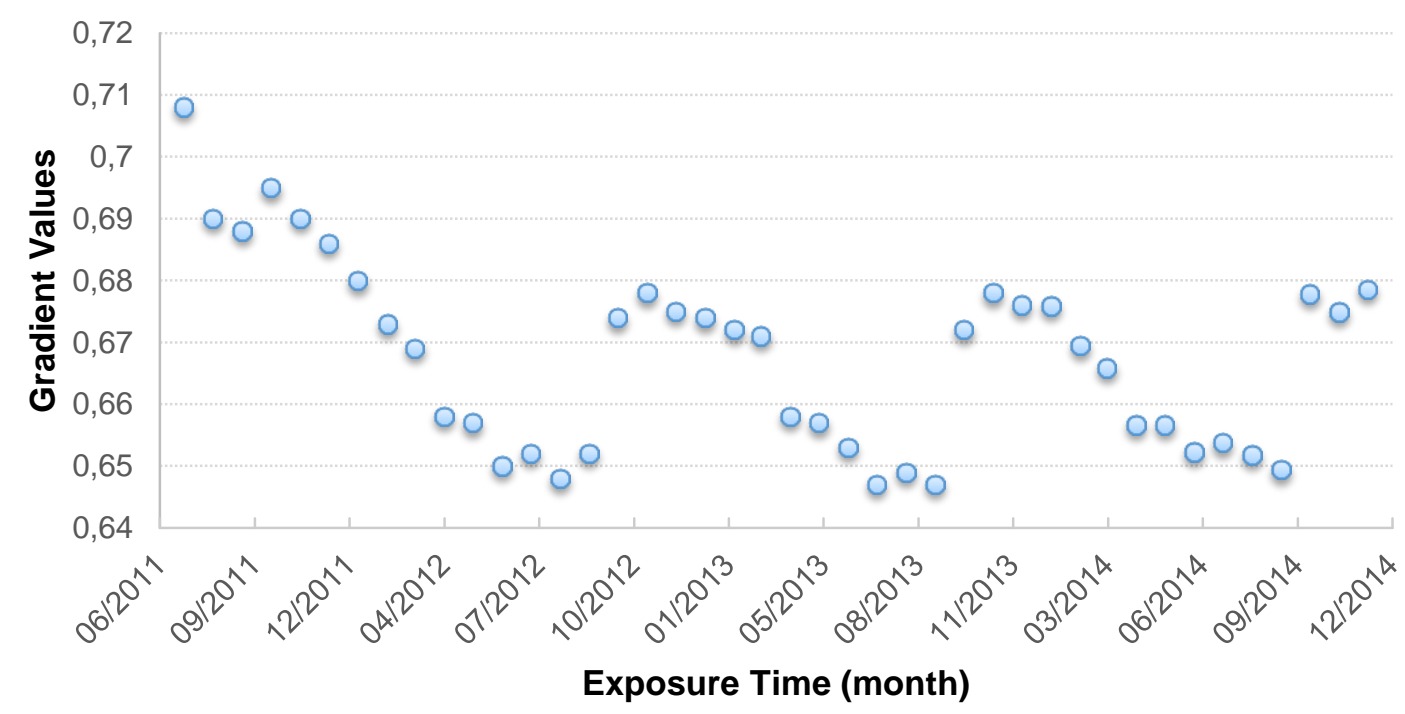

Fig. 10. Gradient values obtained along the monitoring campaign.

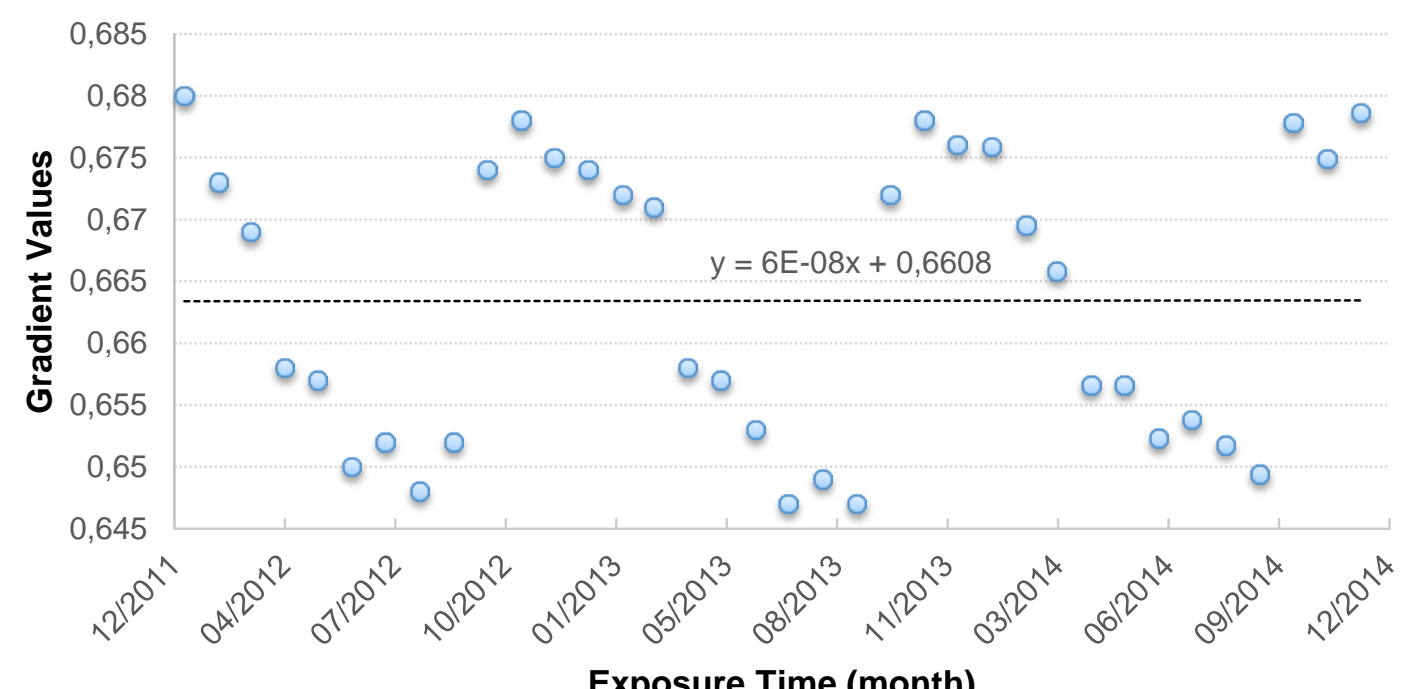

Fig. 11. Gradient values obtained the last two years.

\subsection{Evolution of solar cell model parameters}

The evolution of the solar cell parameters reflects the behaviour of the TFPV modules under seasonal climatic variation. The following figures show the monthly average value of each one of the solar cell model extracted parameters during the whole monitoring period.

Fig. 12 illustrates the evolution of the ideality factor $n$, obtained by the parameter extraction technique. It can be seen that the variation of the values 
obtained is very small and follows the seasonal changes. The ideality factor shows a small reduction in summer while it increases in winter periods. However, the value of $n$ fluctuates around a mean value of $n=1.2$ and the seasonal variations are small. This fact indicates that the diode included in the equivalent circuit of the solar cell corresponding to the five parameter model is dominated by the $\mu \mathrm{c}-\mathrm{Si}: \mathrm{H}$ substrate [Brammer, T. and Stiebig, H., 2006].

In summer months, it can be seen that there is an improvement in the material characteristics especially in the amorphous layer, caused by the higher temperatures reached by the solar cells. This improvement is due to an increase in charge carrier lifetime and a reduction in band gap [Meyer and van Dyk, 2003; Radue and van Dyk, 2010], that's why the values of $n$ are reduced. On the other hand, in winter months, the extracted values of the ideality factor $n$ are increased due to the increase of the recombination current [Radue and van Dyk, 2010].

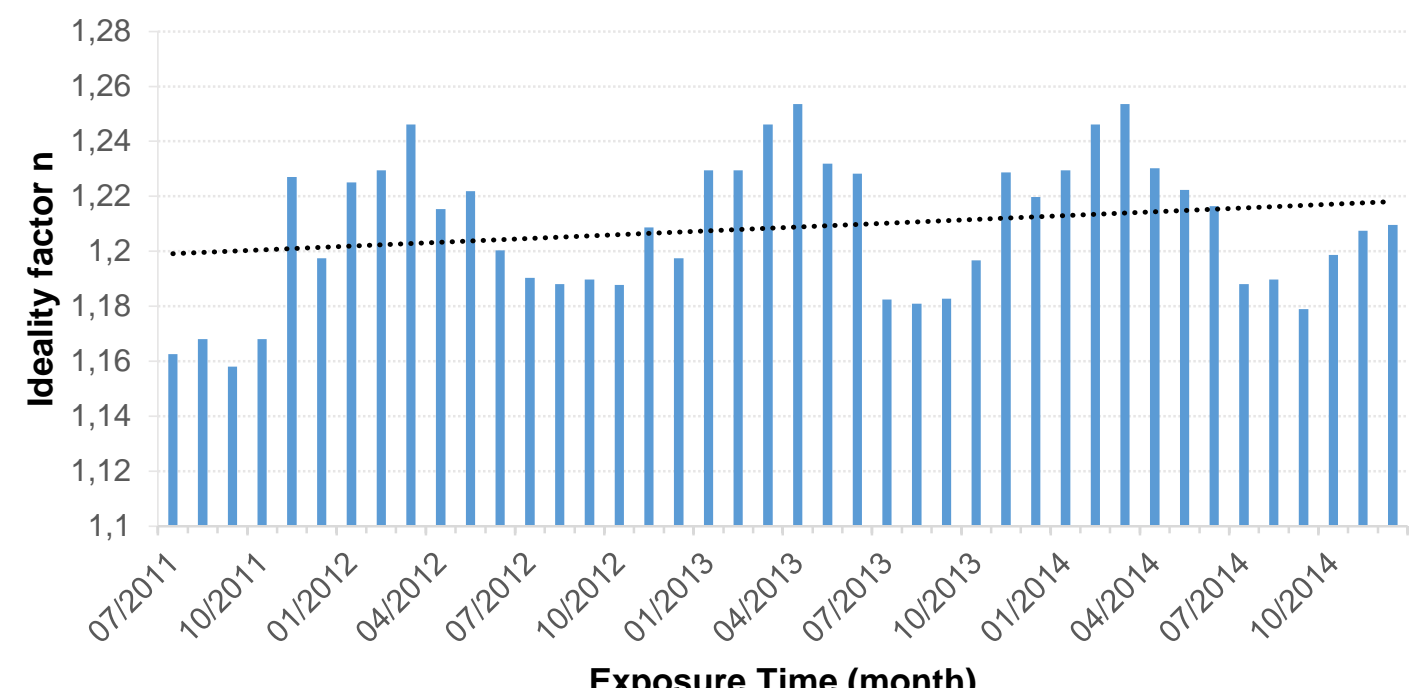

Fig. 12. Average values of $n$ obtained by using the parameter extraction algorithm.

The evolution of the saturation current, $I_{0}$, shown in Fig.13 demonstrates how the variations of the temperature can affect the bandgap of the solar cell material given by the Eq. (9). The evolution of $I_{0}$ is opposite to the trend shown by the ideality factor, $\mathrm{n}$, as expected. 
The open-circuit voltage is decreased due to the decrease of the bandgap caused by the higher temperatures in summer season [Radue and van dyk 2010]. The combination of bandgap reduction and strong increase of temperature in summer periods along with the increase in short circuit current due to LID effect lead to an increase of the saturation current despite the reduction of recombination effects in summer. As can be seen in Fig. 13, Io varies from values in the order of $10^{-7} \mathrm{~A}$ to values around $10^{-8} \mathrm{~A}$ in winter periods. This variation of about one order of magnitude also explains the small seasonal changes observed in the value of the ideality factor.

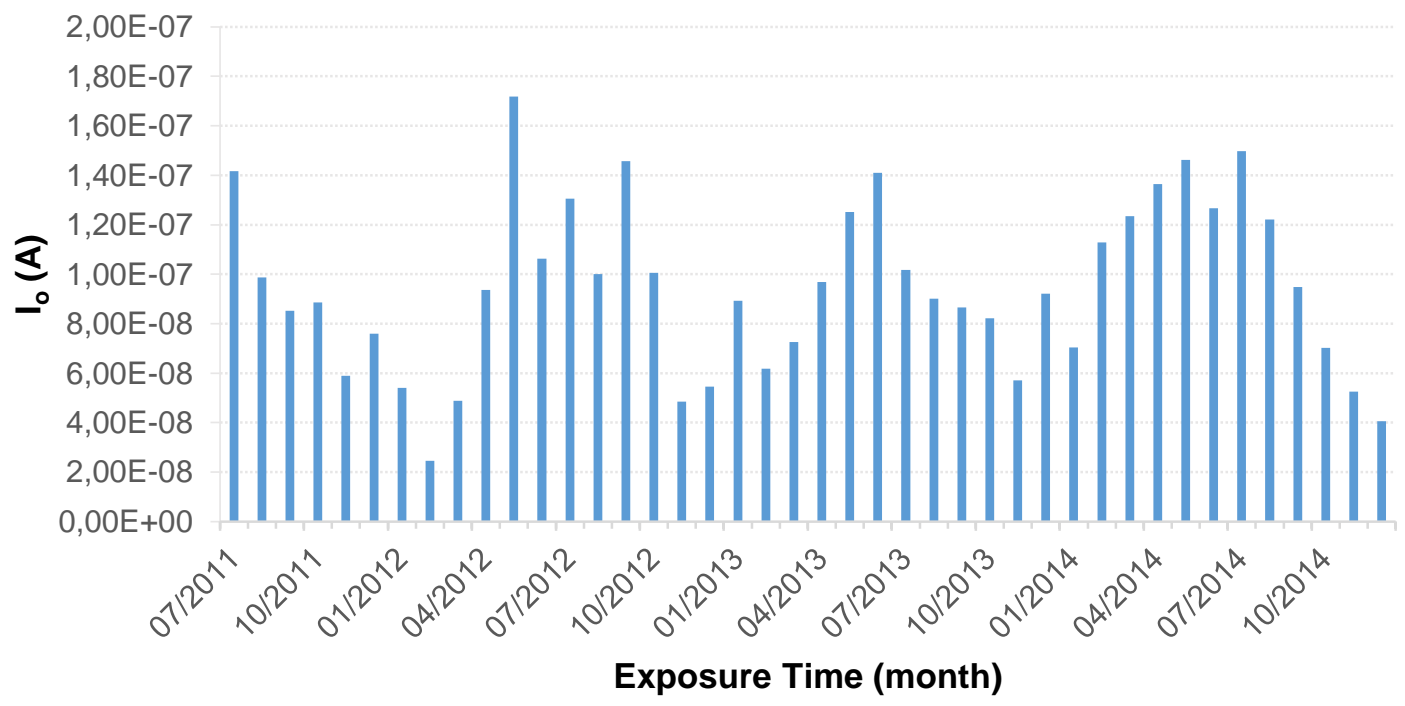

Fig. 13. Evolution of $I_{0}$; Average values obtained by using the parameter extraction algorithm.

The continuing decrease in short circuit current, $I_{s c}$, throughout the first four months of the deployment period can be observed in Fig. 14. After that it shows a more stable trend following the seasonal changes.

The improvement in output current during summer time is due to the effect of solar spectral irradiance and to thermal-recovery of the LID affecting the thin film amorphous layer [Carlson, 2003; Radue and van Dyk, 2010]. The lower temperatures in winter also reduce the thermal recovery rate for the a-Si solar cells. The minimum value of $I_{s c}$ in the worst winter months is approximately $12 \%$ less than the peak value of this parameter for the a-Si/ $\mu \mathrm{c}-\mathrm{Si}$ solar cells. 
This reduction is very small compared to the observed on a-Si PV modules in outdoor conditions of work at the same location [Kichou et al., 2016].

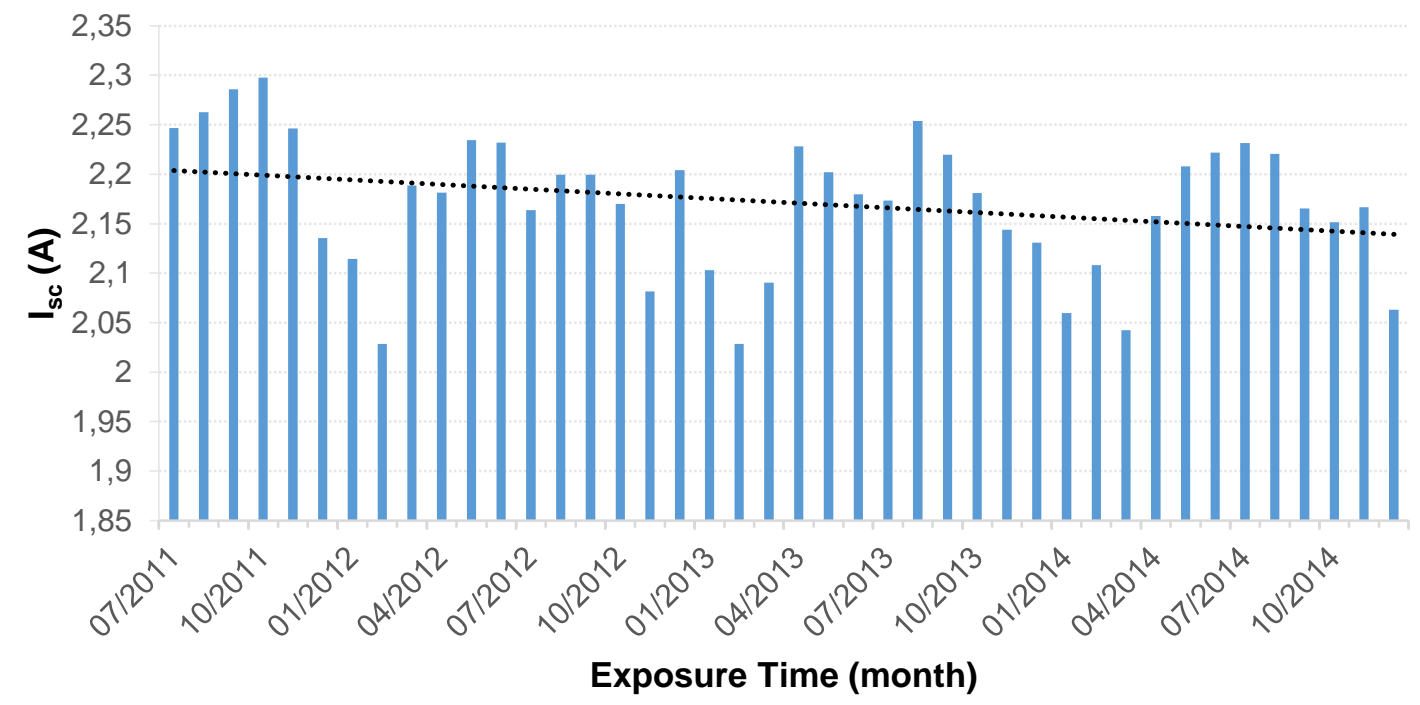

Fig. 14. Evolution of $I_{s c}$ : Average values obtained by using the parameter extraction algorithm.

Fig. 15 shows the evolution of the mean monthly value obtained by the parameter extraction algorithm for the shunt resistance, $R_{s h}$, along the monitoring period. An important decrease of $R_{s h}$ can be observed after the first four months of exposure under outdoor conditions, where the value of $R_{s h}$ is reduced by $56 \%$ respect to its initial value.

The reduction of $R_{s h}$ in TF solar cells under outdoor exposure for long periods of time has been previously reported [Radue and van Dyk, 2010; van Dyk and Meyer, 2004]. On the other hand, after the stabilization period, the evolution of $R_{s h}$ shows the same seasonal trend that the evolution of the output power of the PV array and $I_{s c}$ as expected. 


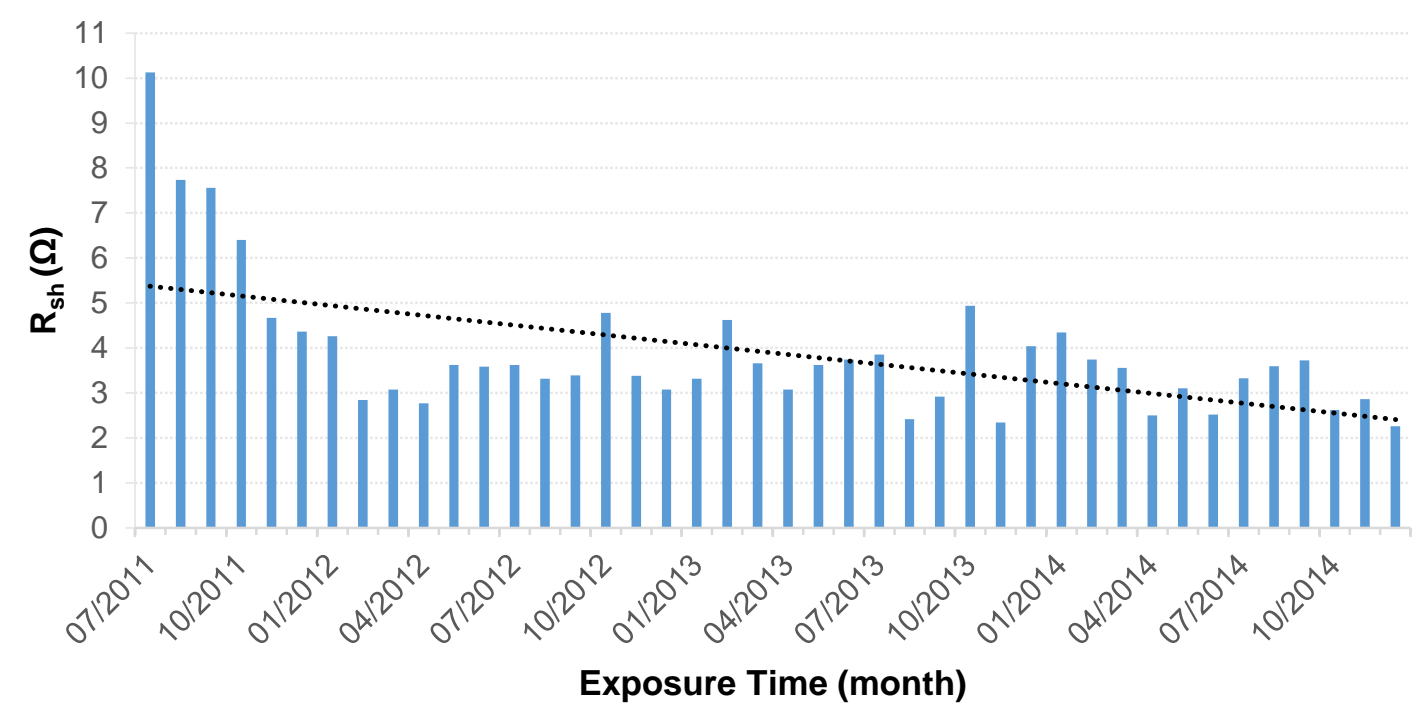

Fig. 15. Evolution of $R_{s h}$ : Mean monthly values obtained.

The series resistance, $R_{S}$, shows a continuing increase along the first months of the monitoring campaign. The variation of the values of $R_{S}$ is very small and it goes from an initial value of $3 \mathrm{~m} \Omega$ to a final value of $6 \mathrm{~m} \Omega$. After the stabilization period, the seasonal effect can also be observed in the trend of $R_{s}$ that presents higher values in winter, with maximum values in the month of December, and reduced values in summer, with minimum values in the month of August. The range of the variation is around $30 \%$ between the peak to peak values of $R_{S}$ in winter and summer. The behaviour of $R_{S}$ shown in Fig. 16 is in accordance with precious works reported in the literature for TF solar cells [Radue and van Dyk, 2010; van Dyk and Meyer, 2004]. 


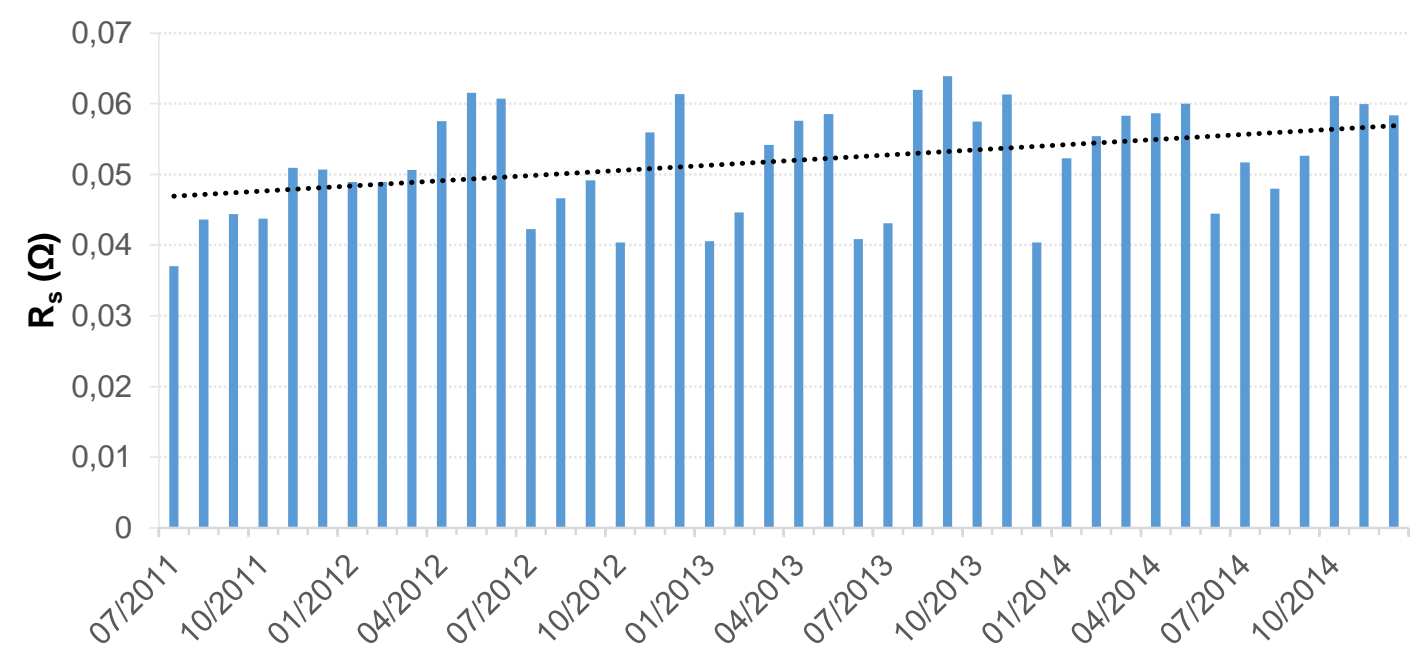

Exposure Time (month)

Fig. 16. Evolution of $R_{s}$ : Mean monthly values obtained.

\section{Conclusion}

The behaviour of a grid connected PV array formed by micromorph TFPV modules situated in Jaén is reflected by the monitored data obtained under outdoor long term exposure of the PV system from July 2011 to December 2014. The degradation modes of the micromorph solar cells and how they affect the performance of the TFPV modules in a relatively dry and sunny inland site with a Continental-Mediterranean climate are addressed in this paper.

From the analysis of the obtained results, by about $12.5 \%$ of reduction of the DC output power of the PV array was observed after the first month of exposure under outdoor conditions. On the other hand, the stabilization period was observed to start after four months of operation with a total reduction of the PV array DC output power of $16.66 \%$. The effect of seasonal oscillation remains after the stabilization period with variations about $3.18 \%$ from the stabilized level of DC output power.

The extracted sets of solar cell model parameters obtained by using the parameter extraction technique are able to reproduce the behaviour of the PV array in real conditions of work with a good accuracy degree. With the proposed approach it is possible to describe the time evolution of all model parameters along the outdoor long term exposure period of the PV system. Moreover, the 
temporal evolution of each one of the model parameters permits achieving a better understanding of the performance changes of the PV modules and the evolution of the output power of the PV array and the degradation rate. Furthermore, the seasonal variation of micromorph PV modules behaviour was also observed in the evolution of the solar cell model parameters. It must be noted that the $\mu-\mathrm{Si}: \mathrm{H}$ bottom cell dominates the evolution of most solar cell parameters, mainly the ideality factor and saturation current, while the evolution of the short circuit current see ms to be more related to the of the behavior of the a_Si:H top cell.

\section{References}

Al-Otaibi, A., Al-Qattan, A., Fairouz, F., \& Al-Mulla, A. , 2015. Performance evaluation of photovoltaic systems on Kuwaiti schools' rooftop. Energy Conversion and Management, 95, 110-119.

Aziz, T., Ketjoy, N., \& Sirisamphanwong, C. (2014, March). Determination of PV module power output degradation after long term operation. In Green Energy for Sustainable Development (ICUE), 2014 International Conference and Utility Exhibition on (pp. 1-6). IEEE. Bouraiou, A., Hamouda, M., Chaker, A., Mostefaoui, M., Lachtar, S., Sadok, M. and Issam, A., 2015. Analysis and evaluation of the impact of climatic conditions on the photovoltaic modules performance in the desert environment. Energy Conversion and Management, 106, 1345-1355.

Brammer, T. and Stiebig, H., 2006. Applying analytical and numerical methods for the analysis of microcrystalline silicon solar cells. Solar energy materials and solar cells, 90 (18), 3021-3030.

Čampa, A., Meier, M., Boccard, M., Mercaldo, L.V., Ghosh, M., Zhang, C., Merdzhanova, T., Krč, J., Haug, F.-J. and Topič, M., 2014. Micromorph silicon solar cell optical performance: Influence of intermediate reflector and front electrode surface texture. Solar Energy Materials \& Solar Cells 130, 401-409.

Carlson, D.E., 2003. Monolithic amorphous silicon alloy solar modules. Sol. Energy Mater. Sol. Cells 78, 627-645. doi:10.1016/S0927-0248(02)00455- 
Chandel, S.S., Nagaraju Naik, M., Sharma, V., Chandel, R., 2015. Degradation analysis of 28 year field exposed mono-c-Si photovoltaic modules of a direct coupled solar water pumping system in western Himalayan region of India. Renew. Energy 78, 193-202. doi:10.1016/j.renene.2015.01.015

Chine W, Mellit A, Pavan AM, Kalogirou SA., 2014. Fault detection method for gridconnected photovoltaic plants. Renew Energy 66, 99-110. http://dx.doi.org/10.1016/j.renene.2013.11.073.

Chouder A, Silvestre S., 2010. Automatic supervision and fault detection of PV systems based on power losses analysis. Energy Convers Manag 51, 1929-1937. http://dx.doi.org/10.1016/j.enconman.2010.02.025.

Chouder A, Silvestre S, Sadaoui N, Rahmani L., 2012. Modeling and simulation of a grid connected PV system based on the evaluation of main PV module parameters. Simul Model Pract Theory 20, 46-58. http://dx.doi.org/10.1016/j.simpat.2011.08.011

Chouder A, Silvestre S, Taghezouit B, Karatepe E., 2013 Monitoring, modelling and simulation of PV systems using LabVIEW. Sol Energy 91, 337-349. http://dx.doi.org/10.1016/j.solener.2012.09.016.

Chouder, A., Silvestre, S., 2009. Analysis Model of Mismatch Power Losses in PV Systems. J. Sol. Energy Eng. 131, 024504. doi:10.1115/1.3097275

Di Vincenzo MC, Infield D., 2013. Detailed PV array model for non-uniform irradiance and its validation against experimental data. Sol Energy 97:

314-331. http://dx.doi.org/10.1016/j.solener.2013.08.030.

Durisch, W., Mayor, J.-C., 2003. Application of a generalized current/voltage model for solar cells to outdoor measurements on a SIEMEN SM 110module. 3rd World Conf. onPhotovoltaic Energy Conversion, 2003. Proc. 2, 1956-1959.

Hussin, M.Z., Shaari, S., Omar, a. M., Zain, Z.M., 2015. Amorphous silicon thin-film: Behaviour of light-induced degradation. Renew. Sustain. Energy Rev. 43, 388-402. doi:10.1016/j.rser.2014.10.093

Jordan, D.C., Kurtz, S.R., 2013. Photovoltaic degradation rates - An Analytical 
Review. Prog. Photovoltaics Res. Appl. 21, 12-29. doi:10.1002/pip.1182

Kaplanis S, Kaplani E. Energy performance and degradation over 20 years performance of BP c-Si PV modules. Simul Model Pract Theory 2011;19:1201-11. doi:10.1016/j.simpat.2010.07.009.

Kichou, S., Silvestre, S., Nofuentes, G., Torres-Ramírez, M., Chouder, A., and Guasch, D., 2016. Characterization of degradation and evaluation of model parameters of amorphous silicon photovoltaic modules under outdoor long term exposure. Energy, 96, 231-241.

Martínez-Moreno, F., Lorenzo, E., Muñoz, J., Moretón, R., 2012. On the testing of large PV arrays. Prog. Photovoltaics Res. Appl. 20, 100-105. doi:10.1002/pip.1102

Meyer, E.L., van Dyk, E.E., 2003. Characterization of degradation in thin-film photovoltaic module performance parameters. Renew. Energy 28, 14551469. doi:10.1016/S0960-1481(02)00062-9

Muñoz J, Lorenzo E, Carrillo JM, Moretón R., 2015. Design of a twin capacitive load and its application to the outdoor rating of photovoltaic modules.

Prog Photovoltaics Res Appl 23, 247-52. http://dx.doi.org/10.1002/pip.2425.

Nofuentes, G., García-Domingo, B., Muñoz, J. V., Chenlo, F., 2014. Analysis of the dependence of the spectral factor of some PV technologies on the solar spectrum distribution. Appl. Energy 113, 302-309.

doi:10.1016/j.apenergy.2013.07.044

Phinikarides, A., Kindyni, N., Makrides, G., Georghiou, G.E., 2014. Review of photovoltaic degradation rate methodologies. Renew. Sustain. Energy Rev. 40, 143-152. doi:10.1016/j.rser.2014.07.155

Radue, C., van Dyk, E.E., 2010. A comparison of degradation in three amorphous silicon PV module technologies. Sol. Energy Mater. Sol. Cells 94, 617-622. doi:10.1016/j.solmat.2009.12.009

Rawat, R., Kaushik, S. C., Sastry, O. S., Singh, Y. K., \& Bora, B., 2016. Energetic and exergetic performance analysis of $\mathrm{CdS} / \mathrm{CdTe}$ based photovoltaic technology in real operating conditions of composite climate. 
Energy Conversion and Management, 110, 42-50.

Ruther, R., Del Cueto, J., Tamizh-Mani, G., Montenegro, a. a., Rummel, S., Anderberg, a., Von Roedern, B., 2008. Performance test of amorphous silicon modules in different climates - Year four: Progress in understanding exposure history stabilization effects. Conf. Rec. IEEE Photovolt. Spec. Conf. doi:10.1109/PVSC.2008.4922773

Shah, A., Moulin, E., \& Ballif, C., 2013. Technological status of plasmadeposited thin-film silicon photovoltaics. Solar Energy Materials and Solar Cells, 119, 311-316.

Sharma, V., Chandel, S.S., 2013. Performance and degradation analysis for long term reliability of solar photovoltaic systems: A review. Renew. Sustain. Energy Rev. 27, 753-767. doi:10.1016/j.rser.2013.07.046

Sharma, V., Sastry, O.S., Kumar, A., Bora, B., Chandel, S.S., 2014.

Degradation analysis of a-Si, (HIT) hetro-junction intrinsic thin layer silicon and $\mathrm{m}$-C-Si solar photovoltaic technologies under outdoor conditions.

Energy 72, 536-546. doi:10.1016/j.energy.2014.05.078

Silvestre, S., da Silva, M. A., Chouder, A., Guasch, D. and Karatepe, E., 2014. New procedure for fault detection in grid connected PV systems based on the evaluation of current and voltage indicators. Energy Conversion and Management, 86, 241-249.

Spanish National Institute of Meteorology, 1997. Guía resumida del clima en España. Series estadísticas (1961-1990). Madrid: Ministry of the Environment, Government of Spain.

Spataru S, Hacke P, Sera D, Packard C, Kerekes T, Teodorescu R., 2015.

Temperaturedependency analysis and correction methods of in situ powerloss estimation for crystalline silicon modules undergoing potential-induced degradation stress testing. Prog Photovoltaics Res Appl 23,1536-1549. http://dx.doi.org/10.1002/pip.2587

Staebler, D. L. and Wronski, C. R.,1977. Reversible conductivity changes in discharge-produced amorphous Si. Applied Physics Letters, 31(4), 292294. doi:10.1016/j.energy.2014.06.077 
Tripathi, B., Yadav, P., Rathod, S., \& Kumar, M. (2014). Performance analysis and comparison of two silicon material based photovoltaic technologies under actual climatic conditions in Western India. Energy Conversion and Management, 80, 97-102.

Van Dyk, E.E., Audouard, a., Meyer, E.L., Woolard, C.D., 2007. Investigation of the degradation of a thin-film hydrogenated amorphous silicon photovoltaic module. Sol. Energy Mater. Sol. Cells 91, 167-173. doi:10.1016/j.solmat.2006.08.001

Van Dyk, E.E., Meyer, E.L., 2004. Analysis of the effect of parasitic resistances on the performance of photovoltaic modules. Renew. Energy 29, 333-344. doi:10.1016/S0960-1481(03)00250-7

Yamawaki, T., Mizukami, S., Yamazaki, A., Takahashi, H., 1997. Thermal recovery effect on light-induced degradation of amorphous silicon solar module under the sunlight. Sol. Energy Mater. Sol. Cells 47, 125-134. doi:10.1016/S0927-0248(97)00033-0 